\title{
NILAI TROMBOSIT DAN HEMATOKRIT DALAM MANIFESTASI PERDARAHAN PASIEN DEMAM BERDARAH DENGUE
}

\author{
Alvinasyrah \\ Fakultas Kedokteran, Universitas Lampung, Jl. Prof. DR. Ir. Sumatri Brojonegoro No.1, Gedong Meneng, \\ Kec. Rajabasa, Kota Bandar Lampung, Lampung, Indonesia 35145 \\ aalvinasyrah@gmail.com (+6285278028216)
}

\begin{abstract}
ABSTRAK
Dengue merupakan infeksi yang disebabkan oleh virus dengue. Demam berdarah dengue merupakan bentuk yang lebih berat dari demam dengue dengan manifestasi klinis berupa manifestasi perdarahan, hepatomegali, dan kegagalan sirkulasi. Penurunan jumlah trombosit dan peningkatan nilai hematokrit menjadi dua tanda yang selalu muncul pada demam berdarah dengue. Tujuan literature review ini yaitu mengetahui pengaruh nilai trombosit dan hematokrit terhadap timbulnya manifestasi perdarahan pada pasien demam berdarah dengue yang merupakan salah satu tanda beratnya infeksi yang terjadi. Metode yang digunakan adalah metode literature review yang didapatkan dari buku dan berbagai jurnal nasional maupun internasional yang diterbitkan dari tahun 2008 hingga tahun 2019 dan berasal dari 3 buku dan 7 artikel yang dapat diakses melalui Google Scholar menggunakan kata kunci trombositopenia, hematokrit, demam berdarah dengue, dan manifestasi perdarahan. Berbagai penelitian yang telah dilakukan disimpulkan bahwa nilai trombosit dapat mempengaruhi manifestasi perdarahan pada pasien demam berdarah dengue sedangkan nilai hematokrit tidak berpengaruh terhadap manifestasi perdarahan.
\end{abstract}

Kata kunci: demam berdarah dengue; manifestasi perdarahan; penurunan nilai trombosit; peningkatan nilai hematokrit

\section{THE VALUE OF TROMBOSITE AND HEMATOCRITE IN THE MANIFESTATION OF BLOODAGE OF DENGUE HEMORRHAGIC FEVER PATIENTS}

\begin{abstract}
Dengue is an infection caused by dengue virus. Dengue hemorrhagic fever is a severe form of dengue fever with clinical manifestations such as bleeding, hepatomegaly, and circulatory failure. Decreased platelet and increased hematocrit are two signs that always appear in dengue hemorrhagic fever. The purpose of this literature review is to determine the effect of platelet and hematocrit value on bleeding manifestations in dengue hemorrhagic fever patients, which is a sign of the severity of the infection. The method used is literature review taken from books, national, and international journals were published from 2008 to 2019 and derived from 3 books and 7 articles which can be accessed through Google Scholar by using the keywords like thrombocytopenia, hematocrit, dengue hemorrhagic fever, and bleeding manifestations. Various studies have concluded that platelet can affect the bleeding manifestations in dengue hemorrhagic fever patients, while hematocrit does not affect the bleeding manifestations.
\end{abstract}

Keywords:decreased platelet, increased hematocrit, dengue hemorrhagic fever, bleeding manifestation 


\section{PENDAHULUAN}

Dengue merupakan penyakit infeksi yang disebabkan oleh virus dengue yang berasal dari genus Flavivirus dan famili Flaviviridae dengan nyamuk Aedes aegypti dan Aedes albopictus sebagai vektor pembawa. Virus dengue tersusun atas rantai tunggal RNA dan memiliki empat serotipe virus, yaitu DEN-1, DEN-2, DEN-3, DEN-4. Infeksi dengue diketahui telah terjadi selama tiga abad terakhir pada wilayah tropis dan subtropis di dunia. Sekitar 2,5 miliar orang di dunia tinggal di daerah endemis dengue berisiko mengalami demam dengue/ demam berdarah dengue dan sekitar 1,3 miliar orang yang berisiko berada di kawasan Asia Tenggara (WHO, 2011).

Pada tahun 2018, ditemukan kasus DBD sebanyak 65.602 kasus dengan 467 orang meninggal dunia di Indonesia. Jumlah tersebut mengalami penurunan dari tahun sebelumnya dengan 68.407 kasus dan 493 orang meninggal dunia pada tahun 2017. Provinsi yang memiliki kasus kesakitan tertinggi adalah Kalimantan Timur sebesar 87,81 per 100.000 penduduk, Kalimantan Tengah sebesar 84,39 per 100.000 penduduk, dan Bengkulu sebesar 72,28 per 100.000 penduduk. Sedangkan angka kematian yang tertinggi akibat DBD terjadi pada provinsi Maluku Utara (3,64\%), Maluku (3,15\%), dan Kalimantan Utara $(1,74 \%)$ (Kemenkes RI, 2019).

Infeksi dengue terbagi menjadi demam dengue (DD) dan demam berdarah dengue (DBD). Adapun manifestasi klinis utama pada demam dengue yaitu ditandai dengan adanya demam tinggi mendadak, sakit kepala, nyeri retroorbital, nyeri sendi, dan nyeri otot. Sedangkan demam berdarah dengue merupakan bentuk yang lebih berat dari demam dengue yang ditandai dengan manifestasi klinis berupa fenomena perdarahan, hepatomegali, dan kegagalan sirkulasi. Manifestasi perdarahan yang ditemukan pada pasien DBD dapat berupa tes torniket positif, pteki pada kulit, ekimosis, epistaksis, perdarahan gusi, dan perdarahan gastrointestinal pada kondisi berat. (Sellahewa, 2013) (Soedarto, 2012).

Trombositopenia (penurunan jumlah trombosit) dan hemokonsentrasi (peningkatan nilai hematokrit) merupakan dua tanda yang selalu muncul pada demam berdarah dengue. Penyebab dari trombositopenia masih kontroversial. Namun, ketika pasien terinfeksi DBD, trombositopenia akan terjadi karena menurunnya pembentukan trombosit di sumsum tulang, meningkatnya destruksi trombosit di sistem retikuloendotel dan agregasi trombosit akibat kerusakan pembuluh endotel. Hemokonsentrasi terjadi dengan adanya peningkatan hematokrit akibat adanya kebocoran plasma ke ruang ekstravaskuler melalui kapiler yang rusak. Akibat adanya kerusakan menimbulkan volume plasma berkurang sehingga pasien mengalami syok hipovolemik dan kegagalan sirkulasi (Suseno \& Nasronudin, 2015).

Literature review ini bertujuan untuk mengetahui pengaruh nilai trombosit 
dan hematokrit terhadap timbulnya manifestasi perdarahan pada pasien demam berdarah dengue yang merupakan salah satu tanda beratnya infeksi yang terjadi.

\section{METODE}

Penulisan artikel ini menggunakan metode literature review. Referensi yang digunakan didapatkan dari buku dan berbagai jurnal nasional maupun internasional yang diterbitkan dari tahun 2008 hingga tahun 2019. Referensi yang digunakan berasal dari 3 buku dan 7 artikel yang dapat diakses melalui Google Scholar menggunakan kata kunci trombosit, hematokrit, demam berdarah dengue, dan manifestasi perdarahan. Referensi yang telah diperoleh kemudian dianalisis dengan metode systematic literature review yang meliputi pengumpulan, evaluasi, dan pengembangan penelitian dengan fokus tertentu.

\section{HASIL}

Hasil penelitian yang telah dilakukan oleh Amala (2019) bahwa ada hubungan antara kadar trombosit dengan manifestasi perdarahan pada pasien DBD di RSUD Dr. Harjono Ponorogo pada tahun 2018. Analisis korelasi juga didapatkan nilai $r=0,388$ yang menunjukkan bahwa kedua variabel memiliki korelasi cukup dan hubungan yang searah. Penelitian ini sesuai dengan penelitian yang dilakukan oleh Bashir, Mohammed, Saeed, \& Ageep (2015) juga menyatakan bahwa ada hubungan yang sangat kuat antara nilai trombosit dengan manifestasi perdarahan. Serta didukung dengan penelitian Anzani (2019) didapatkan bahwa $p$-value $0,015<0,05$ yang artinya terdapat hubungan antara jumlah trombosit terhadap manifestasi perdarahan dengan nilai trombosit kurang dari $100.000 / \mathrm{mm}^{3}$ lebih banyak menyebabkan manifestasi perdarahan sedang.

Penelitian Anzani (2019) didapatkan nilai $p$-value sebesar 1,00 yang berarti tidak adanya hubungan antara nilai hematokrit dengan manifestasi perdarahan. Penelitian ini selaras dengan penelitian Livina, Rotty, \& Panda (2014) yang menyatakan tidak terdapat hubungan antara hematokrit dengan manifestasi perdarahan pada pasien DBD, serta penelitian Amala (2019), menyatakan tidak ada hubungan dengan analisis korelasi sebesar $\mathrm{r}=$ 0,211 dengan arti bahwa korelasi sangat lemah dan hubungan kedua variabel tidak searah.

\section{PEMBAHASAN}

Infeksi dengue merupakan penyakit infeksi yang disebabkan oleh virus dengue dengan nyamuk Aedes aegypti dan Aedes albopictus sebagai vektor pembawa serta memiliki empat jenis serotipe, yaitu DEN-1, DEN-2, DEN-3, dan DEN-4. Demam berdarah dengue adalah salah satu bentuk infeksi dengue yang memiliki gejala yang lebih berat. Demam berdarah dengue ditandai dengan adanya manifestasi klinis yang khas yaitu berupa manifestasi perdarahan dan kegagalan sirkulasi yang diakibatkan terjadinya kebocoran plasma. Manifestasi perdarahan yang terjadi pada demam berdarah dengue 
sering ditandai dengan adanya tes torniket positif, pteki, epistaksis, perdarahan gusi, serta perdarahan gastrointestinal. Dalam penegakan diagnosis demam berdarah dengue dapat dilakukan dengan melihat manifestasi klinis dan pemeriksaan laboratorium. Adapun pemeriksaan laboratorium yang dapat diperiksa pada demam berdarah dengue adalah nilai trombosit dan hematokrit (Soedarto, 2012) (Sellahewa, 2013) (WHO, 2011).

Manifestasi perdarahan pada DBD dapat dipengaruhi dengan jumlah trombosit yang rendah atau dikenal dengan trombositopenia (Bashir, Mohammed, Saeed, \& Ageep, 2015). Trombosit memiliki peran dalam menjaga keseimbangan pembuluh darah dengan cara adhesi, aktivasi koagulasi, dan agregasi trombosit. Ketika virus dengue masuk ke dalam tubuh dan membentuk kompleks virus antibodi mengakibatkan pengaktifan sistem koagulasi dan proses agregasi trombosit menjadi terganggu, sehingga nilai trombosit dapat mengalami penurunan. Penurunan nilai trombosit terjadi karena berkurangnya produksi trombosit didalam sumsum tulang, peningkatan destruksi trombosit didalam sistem retikuloendotel, dan terjadinya agregasi trombosit akibat disfungsi dari endotel. Agregasi trombosit akan memicu pengeluaran platelet faktor III sebagai penyebab terjadinya koagulopati konsumtif atau koagulasi intravaskuler diseminata menyebabkan peningkatan pada FDP (fibrinogen degradation products) dan berakibat turunnya faktor koagulasi. Lamanya gangguan aktivasi sistem koagulasi dan fibrinolisis yang terjadi mengakibatkan faktor koagulasi mengalami penurunan, sehingga manifestasi perdarahan dapat menjadi lebih berat (Suseno \& Nasronudin, 2015) (Soedarto, 2012) (Rena, Utama, $\& \mathrm{M}, 2009)$.

Penurunan nilai trombosit sering diikuti dengan adanya peningkatan nilai hematokrit. Peningkatan nilai hematokrit dapat mengakibatkan kebocoran plasma yang menggambarkan keadaan kritis dari demam berdarah dengue (Soedarto, 2012). Namun pada beberapa kasus DBD berat yang disertai perdarahan, nilai hematokrit cenderung tidak meningkat, bahkan mengalami penurunan. Sehingga pada beberapa penelitian tidak ditemukan adanya pengaruh nilai hematokrit terhadap timbulnya manifestasi perdarahan (Rena, Utama, \& M, 2009).

\section{SIMPULAN}

Nilai trombosit dapat mempengaruhi manifestasi perdarahan pada pasien demam berdarah dengue sedangkan nilai hematokrit tidak berpengaruh terhadap manifestasi perdarahan.

\section{DAFTAR PUSTAKA}

Amala, F. N. (2019). Hubungan kadar trombosit dan peningkatan hematokrit dengan manifestasi perdarahan pasien DBD anak di RSUD Dr. Harjono Ponorogo. Surakarta: Universitas Muhammadiyah Surakarta.

Anzani, B. P. (2019). Hasil pemeriksaan darah rutin terhadap manifestasi perdarahan pada anak dengan diagnosis infeksi dengue di RS 
Dr. A. Dadi Tjokrodipo. Jurnal Kesehatan Poltekkes Palembang, 14(1), 25-31

DOI: https://doi.org/10.36086/jpp. v14i1.402.

Bashir, A. B., Mohammed, B. A., Saeed, O. K., \& Ageep, A. K. (2015). Thrombocytopenia and bleeding manifestations among patients with dengue virus infection in Port Sudan, Red Sea State of Sudan. Journal of Infectious Diseases and Immunity, 7(2), 7-13. DOI: 10.5897/J IDI2014.0143.

Kemenkes RI. (2019). Profil kesehatan indonesia 2018. Jakarta: Kementerian Kesehatan Republik Indonesia.

Livina, A., Rotty, L. W., \& Panda, A. L. (2014). Hubungan trombositopenia dan hematokrit dengan manifestasi perdarahan pada penderita demam dengue dan demam berdarah dengue. Jurnal E-Clinic (ECL), 2(1), 1-8. DOI:

https://doi.org/10.35790/ecl.2.1.20 14.3610 .

Rena, N. M., Utama, S., \& M, T. P. (2009). Kelainan Hematologi pada Demam Berdarah Dengue. Jurnal Penyakit Dalam, 10(3), 218-225

Sellahewa, K. H. (2013). Pathogenesis of dengue haemorrhagic fever and its impact on case management. Hindawi Publishing Corporation, 1-6.

https://doi.org/10.5402/2013/5716 $\underline{46}$.

Soedarto. (2012). Demam berdarah dengue. Surabaya: CV. Sagung Seto.
Suseno, A., \& Nasronudin. (2015). Pathogenesis of hemorrhagic due to dengue virus. Indonesian Journal of Tropical and Infectious Disease, 5(4), 107-111. http://dx.doi.org/10.20473/ijtid.v5 i4.2009.

WHO. (2011). Comprehensive guidelines for prevention and control of dengue and dengue haemorrhagic fever. Revised and expanded edition. New Delhi: World Health Organization. 
Jurnal Penelitian Perawat Profesional, Volume 3 No 1 Hal 153 - 158, Februari 2021 Global Health Science Group 